\title{
Cardioembolic Caudate Infarction as a Cause of Hemichorea in Lupus Anticoagulant Syndrome
}

\author{
Andrew Kirk and Sheila Rutledge Harding
}

\begin{abstract}
An association exists between antiphospholipid antibodies and chorea. As these antibodies are associated with thrombosis, it has been suggested that cerebral infarction might cause chorea. However, CT and MRI typically do not demonstrate focal basal ganglionic lesions in such patients and an autoimmune mechanism for chorea has also been proposed. We report a young woman with left hemichorea and dyspnea. She was found to have lupus anticoagulant, large aortic and tricuspid vegetations, and pulmonary emboli. CT and MRI showed a small lesion in the head of the right caudate. In the presence of a definite cardiac source for emboli (valvular vegetations) with embolic activity (pulmonary emboli), it is likely that this patient's hemichorea was caused by cardioembolic caudate infarction.

RÉSUMÉ: Infarctus du noyau caudé par embolisation d'origine cardiaque comme cause d'hémichorée dans le syndrome anticoagulant lupique. Il existe une association entre les anticorps antiphospholipides et la chorée. Comme ces anticorps sont associés à la thrombose, il a été suggéré qu'un infarctus cérébral peut causer une chorée. Cependant, le CT et la MRI ne mettent habituellement pas en évidence de lésion des noyaux gris centraux chez ces patients et un mécanisme auto-immun a été invoqué comme étiologie de la chorée. Nous rapportons le cas d'une jeune femme avec une hémichorée gauche et une dyspnée. On a mis en évidence chez-elle un anticoagulant lupique, de grosses végétations aortiques et tricuspidiennes et des embolies pulmonaires. Le CT et la MRI ont montré une petite lésion de la tête du noyau caudé droit. Vu la présence d'un foyer cardiaque évident d'embolisation (végétations valvulaires) avec activité embolique (embolies pulmonaires), il est probable qu'un infarctus du noyau caudé par embolisation d'origine cardiaque soit la cause de l'hémichorée chez cette patiente.
\end{abstract}

Can.J. Neurol. Sci. 1993; 20: 162-164

Lupus anticoagulant (LAC) is an antiphospholipid antibody with in vitro anticoagulant properties, tending to prolong the partial thromboplastin time. Clinically, LAC has been associated with a tendency to venous and arterial thrombosis.' Although initially described in systemic lupus erythematosus (SLE), many patients with LAC do not meet criteria for SLE. ${ }^{2}$ LAC has also been associated with an increased risk for spontaneous abortion, ${ }^{3}$ stroke,$^{4-7}$ migraine, ${ }^{8}$ cardiac valvular disease,,${ }^{9.10}$ and chorea. $11-13$

The mechanism of chorea in patients with LAC is unknown. It has been suggested that cerebral infarction due to thrombosis or embolism might cause chorea. ${ }^{11.14}$ However, CT and MRI typically do not demonstrate focal basal ganglionic lesions in patients with chorea. ${ }^{11,12,14}$ This negative finding has been used as support for an alternative hypothesis that antibodies may bind directly to phospholipid in the basal ganglia. 11,12,14-17

This report concerns a 21-year-old woman with hemichorea, venous thrombosis, recurrent spontaneous abortions, pulmonary embolism, and severe cardiac valvular disease in association with LAC. Evidence is presented to suggest that chorea was due to cardioembolic caudate infarction.

\section{CASE REPORT}

\section{History and Physical Examination}

In August, 1991, H.G., a 21 -year-old woman, presented to Royal University Hospital in Saskatoon because of involuntary movements of her left side. These had begun suddenly three months before and were not worsening. The movements were always present during wakefulness, were worse when she was nervous and disappeared during sleep. There were no other neurologic complaints.

In 1989, after a year on an oral contraceptive, she was treated elsewhere for phlebothrombosis of her right arm and left leg. After discontinuing the contraceptive, she had no further thrombotic problems. In May, 1990, she gave birth to a daughter. The pregnancy was complicated by hypertension and proteinuria. An episode of confusion followed within one week of beginning antihypertensive treatment with atenolol at 28 weeks gestation. This resolved within a day of stopping the drug. Delivery was by Caesarean section because of hypertension and

From the Divisions of Neurology (A.K.) and Hematology (S.R.H.) of the Department of Medicine, University of Saskatchewan, Saskatoon Received August 31, 1992. Accepted in final form November 9, 1992

Presented in part at the XXVIIth Canadian Congress of Neurological Sciences, Winnipeg, Manitoba, June 27, 1992

Reprint requests to: Dr. Andrew Kirk, Department of Medicine, Division of Neurology, Royal University Hospital, Saskatoon, Saskatchewan, Canada S7N 0X0 
intrauterine growth retardation. Spontaneous first trimester abortions occurred in December, 1990 and February, 1991.

H.G. had no history of skin rash, serositis, arthritis, photosensitivity, seizures, mucosal ulceration, alopecia, rheumatic fever, or cardiac disease. At the time of admission she was on no medications. There was no history of treatment with psychotropic drugs. She had smoked one pack daily for three years.

H.G.'s brother had died at age 21 of Hodgkin's disease. There was no family history of movement disorders or collagen-vascular disease.

Neurologic examination was normal except for left hemichorea. There were frequent small random movements of the fingers, flexionextension movements at the wrist and, less often, pronation-supination at the elbow and abduction at the shoulder. Occasional twitches were seen in the left lower face and at the ankle. Pending investigation, treatment with haloperidol $1 \mathrm{mg}$ twice daily was instituted and the hemichorea stopped completely within a few days. However, two weeks later, H.G. developed exertional dyspnea and was admitted to hospital. Murmurs of tricuspid regurgitation and stenosis and of aortic regurgitation were heard.

\section{Investigations}

CT scan showed a small non-enhancing lucency in the head of the right caudate nucleus (Figure 1). MRI scan showed an area of T2 hyperintensity in the same location as well as two similar lesions in the left occipital white matter. The prothrombin time was normal. The activated partial thromboplastin time (aPTT) with Organon Teknika's Automated APTT was slightly prolonged (36 sec; control 29). The aPTT with a more LAC-sensitive reagent (Organon Teknika's Platelin Excel LS) ${ }^{18}$ was markedly prolonged ( $60 \mathrm{sec}$; control 28 ). The addition of normal plasma to the sample failed to correct the prolonged aPTT, confirming the presence of an anticoagulant. The platelet neutralization procedure ${ }^{19}$ was strongly positive, demonstrating the phospholipid dependence of the anticoagulant. IgG anticardiolipin antibodies were present at 57.7 $\mathrm{mg} / \mathrm{L}$ (normal 0.0 to 23.0 ) but IgM antibodies were negative. Echocardiography showed a 4 by $11 \mathrm{~mm}$ mass attached to the aortic valve and protruding into the left ventricular outflow tract during diastole resulting in severe aortic regurgitation. A 23 by $11 \mathrm{~mm}$ bi-lobed mass was attached to the tricuspid valve causing mild tricuspid stenosis and moderate tricuspid regurgitation. Ventilation lung scan was normal. Perfusion lung scan showed a large perfusion defect in the right lower lobe suggestive of pulmonary thromboembolism.

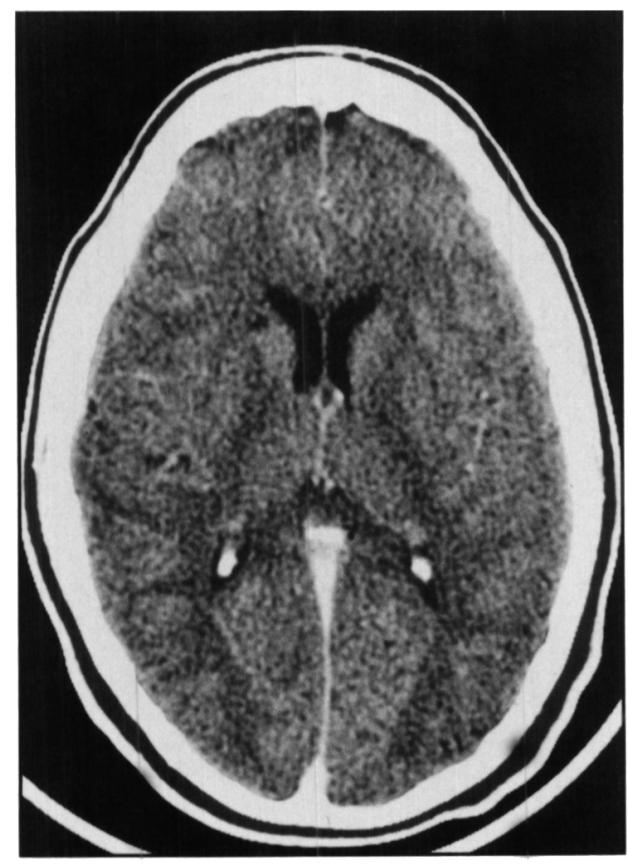

Figure I $-C T$ scan showing right caudate lucency.
A twenty-four hour urine collection contained $3.46 \mathrm{~g}$ of protein. Hemoglobin, white blood cell and platelet count, chest X-ray, impedance plethysmography of the lower limbs, antinuclear antibody, anti-DNA antibodies, VDRL, rheumatoid factor, LE cell test, three sets of blood cultures, complement levels, plasma amino acids, anti-thrombin III, protein $\mathrm{C}$, copper, ceruloplasmin, thyroid function and other routine biochemical tests were all normal.

\section{Course}

H.G. was anticoagulated with heparin and subsequently with warfarin. Her dyspnea rapidly resolved. Haloperidol was discontinued after three weeks and chorea has not returned. On long-term anticoagulation, H.G. remains completely asymptomatic one year after the onset of hemichorea but continues to be followed for a lesser degree of proteinuria and for her valvular lesions which were unchanged on repeat echocardiogram two months after the first.

\section{Discussion}

This patient presented with several clinical problems often associated with LAC - hemichorea, venous thrombosis, recurrent spontaneous abortions, and cardiac valvular disease. CT and MRI showed a lesion consistent with a caudate infarct in lenticulostriate territory. Striatal infarcts are well-described in patients with acute contralateral hemichorea ${ }^{20}$ but not all patients with caudate infarction develop chorea. The clinical presentation makes it likely that this patient's chorea was due to the contralateral caudate lesion. Although often attributable to small vessel disease in elderly patients with diabetes or hypertension, ${ }^{20}$ emboli to this region occur and may be more common in children and adolescents. ${ }^{21,22}$ Chorea and caudate infarction have been reported in bacterial endocarditis. ${ }^{23}$

H.G. had echocardiographically confirmed severe left and right heart valvular disease as has been reported in patients with LAC. There was also evidence for pulmonary embolism, presumably related to her tricuspid vegetations. Embolic cerebral infarction attributable to valvular disease has been reported in patients with circulating LAC, ${ }^{9.15 .24-26}$ although not previously as a cause of chorea. Although in situ thrombosis could also explain this patient's caudate lesion, the clinical circumstances support the likelihood of a cardioembolic source.

As chorea has been reported in LAC patients without evidence of caudate infarction, ${ }^{11.12}$ it is likely that there is more than one mechanism by which chorea can occur in the LAC syndrome. Focal lesions may be more common in patients with hemichorea while an autoimmune mechanism may be more likely in patients with bilateral symptoms. Nevertheless, these findings suggest a relationship between $\mathrm{LAC}$, cardiac vegetations, caudate infarction, and chorea. It is important that patients presenting with hemichorea and LAC undergo echocardiography to identify a source of emboli, as further complications may be preventable with anticoagulation.

\section{REFERENCES}

1. Boey ML, Colaco CB, Gharavi AE, et al. Thrombosis in SLE: striking association with the presence of circulating 'lupus' anticoagulant. Br Med J 1983; 287: 1021-1023.

2. Gastineau DA, Kazmier FJ, Nichols WL, et al. Lupus anticoagulant: an analysis of the clinical and laboratory features of 219 cases. Am J Hematol 1985; 19: 265-275.

3. Hughes GRV. Thrombosis, abortion, cerebral disease and the lupus anticoagulant. Br Med J 1983; 287: 1088-1089.

4. Briley DP, Coull BM, Goodnight SH Jr. Neurological disease associated with antiphospholipid antibodies. Ann Neurol 1989; 25: 221-227. 
5. Harris EN, Gharavi AE, Asherson RA, et al. Cerebral infarction in systemic lupus: association with anticardiolipin antibodies. Clin Exp Rheumatol 1984; 2: 47-51.

6. Levine SR, Welch KMA. Cerebrovascular ischemia associated with lupus anticoagulant. Stroke 1987; 18: 257-263.

7. Asherson RA, Khamashta MA, Gil A, et al. Cerebrovascular disease and antiphospholipid antibodies in systemic lupus erythematosus, lupus-like disease, and the primary antiphospholipid syndrome. Am J Med 1989; 86: 391-399.

8. Hogan MJ, Brunet DG, Ford PM, Lillicrap D. Lupus anticoagulant, antiphospholipid antibodies and migraine. Can J Neurol Sci 1988; 15: 420-425.

9. Ford PM, Ford SE, Lillicrap DP. Association of lupus anticoagulant with severe valvular heart disease in systemic lupus erythematosus. J Rheumatol 1988; 15: 597-600.

10. Asherson RA, Lubbe WF. Cerebral and valve lesions in SLE: association with antiphospholipid antibodies. J Rheumatol 1988; 15: 539-543.

11. Asherson RA, Derksen RHWM, Harris EN. Chorea in systemic lupus erythematosus and "lupus-like" disease: association with antiphospholipid antibodies. Semin Arthr Rheum 1987; 16: 253 259.

12. Bruyn GW, Padberg G. Chorea and systemic lupus erythematosus - a critical review. Eur Neurol 1984; 23: 435-448.

13. Gutrecht JA, Kattwinkel N, Stillman MJ. Retinal migraine, chorea, and retinal artery thrombosis in a patient with primary antiphospholipid antibody syndrome. J Neurol 1991; 238: 55-56.

14. McCune WJ, Golbus J. Neuropsychiatric lupus. Rheum Dis Clin N Am 1988; 14: 149-167.

15. Levine SR, Welch KMA. The spectrum of neurologic disease associated with antiphospholipid antibodies - lupus anticoagulant and anticardiolipin antibodies. Arch Neurol 1987; 44: 876-883.
16. Bresnihan B. CNS lupus. Clin Rheum Dis 1982; 183-195.

17. Antolin J, Amerigo MJ, Gomez E, et al. Chorea and systemic lupus erythematosus. Rev Clin Esp 1990; 187: 346-347.

18. Brandt JT, Triplett DA, Musgrave K, Orr C. The sensitivity of different coagulation reagents to the presence of lupus anticoagulants. Arch Pathol Lab Med 1987; 111: 120-124.

19. Triplett DA, Brandt JT, Kaczor D, Schaeffer J. Laboratory diagnosis of lupus inhibitors: a comparison of the tissue thromboplastin inhibitor procedure with a new platelet neutralization procedure. Am J Clin Pathol 1983; 79: 678-682.

20. Lowney SP, Gilbert JJ. Hemichorea and hemiballismus: recent concepts. Clin Neuropathol 1990; 9: 46-50.

21. Mohr JP. Clinical syndromes of middle cerebral territory infarction. In: Barnett HJM, Mohr JP, Stein BM, Yatsu FM, eds. Stroke: Pathophysiology, Diagnosis, and Management. New York: Churchill Livingstone 1986; 401.

22. Davison C, Goodhart SP. Monochorea and somatotopic localization. Arch Neurol Psychiatry 1940; 43: 792-803.

23. Medley RK. Chorea and bacterial endocarditis. Br Med J 1963; 1: 861-862.

24. Young SM, Fisher M, Sigsbee A, Errichetti A. Cardiogenic brain embolism and lupus anticoagulant. Ann Neurol 1989; 26: 390-392.

25. Anderson D, Bell D, Lodge R, Grant E. Recurrent cerebral ischemia and mitral valve vegetation in a patient with antiphospholipid antibodies. J Rheumatol 1987; 14:839-841.

26. D'Alton JG, Preston DN, Bormanis J, et al. Multiple transient ischemic attacks, lupus anticoagulant and verrucous endocarditis. Stroke 1985; 16: 512-514. 